\title{
Magadan Diocese: Overcoming the Crisis of Spirituality in Modern Times
}

\author{
Dmitriy I. PROSYANIK \\ The Diocese of Magadan and Sinegorye \\ Russian Orthodox Church \\ 1, Sobornaya ploschad (Cathedral Square), Magadan, 685000, Russia \\ E-mail: dimitrianmagadan@yandex.ru
}

\begin{abstract}
In this article, we examine the history of the Russian Orthodox Church in the territory of the Magadan region: we present its periodization and factual material for each period. The objective of this study is the systematization of historical material for a holistic understanding of the history of Orthodoxy in the territory of the Magadan region. In this study, we use mainly descriptive and historical methods, synthesis, apply to the elements of axiological analysis. A significant feature of the article is the comprehensive coverage of the history of Orthodoxy in the territory of the Magadan region. Our study results in the following periodization of the history of Orthodoxy in the Magadan region: the Christianization of the region (17-20 centuries), the decline in the atheist state period (1917-1989), and the revival of spiritual life in the 1990s (since 1989 until nowadays).
\end{abstract}

Keywords: Magadan; Orthodoxy; crisis; spirituality; The Magadan Diocese of the Russian Orthodox Church.

\section{Introduction}

The history of religion is a rather specific area of scientific knowledge, which, as a rule, is rarely addressed by the bulk of researchers. As for the Magadan region, nowadays there are only a small number of researchers and scientific articles on the history of the Russian Orthodox Church. Among them, there are remarkable studies of Khakhovskaya (2004), Aruyeva (2015), and Matyushova (2018). But they all are of piecewise nature. Neither this topic is reflected in the studies of foreign authors. Mostly their interest lies in the history of the dark past of the Kolyma camps (Onion, Sullivan, Mullen, 2018; Barenberg, Wilson, Kinnear, Maddox, Viola, 2017), the analysis of political and economic processes (Hanson, 2001), a brief history of Russia (Engel, Martin, 2015), general characteristics of religions in Russia (Knox, 2005; Steinberg, Coleman, 2007), or in interviewing residents of Magadan (Higgins, 2019). The main problem is the lack of description and systematization of integral data on the history of Orthodoxy in the Kolyma land. The presence of this gap in the history of the Magadan region and the need to increase new knowledge determines the relevance of this study.

The objective of our study is a holistic understanding of the history of Orthodoxy in the territory of the Magadan region.

Research problems are - 1) formation of historical periodization; 2) a description of each period, from the beginning of the Christianization of the region to the present day.

\section{Methods}

We based our data search for the article on the best practices from the experience as an employee of the information department of the Magadan diocese: news articles, press releases of the Magadan diocese, working materials for the book "Orthodox Kolyma: dedicated to the 25th anniversary of the Magadan diocese" (John (Pavlikhin), archbishop of Magadan and Sinegorye, 2016), materials of the special project of the diocese - the website "New Martyrs and Confessors of Kolyma". The article also presents quantitative statistics from annual reports on the activities of the Magadan and Sinegorye diocese. We described the history of the first two periods based on a synthesis of data 
from modern historical science and modern scientific articles by Magadan researchers, personal memories and witnesses of Kolyma clergy and new martyrs' relatives.

\section{Results}

We focus on the principle of relations with the state when we present the periodization. Three consistent and clear periods are distinguished: Christianization of the region (17-20 centuries), the decline during the years of the atheist state (1917-1989), and the revival of spiritual life in the 1990s (from 1989 to the present).

1. Magadan diocese: historical development and prerequisites for spiritual prosperity. The development of the territory of the Magadan region in the 17th century is associated with the names of famous Russian explorers - Cossacks Moskvin, Dezhnev, and their associates. With the advent of Orthodox people on this land, settlements began to be built in which chapels and temples were erected. Not only those who developed new lands needed spiritual support. Thanks to the hard work of the missionary priests, Christianization and enlightenment of the local indigenous population were actively carried out. The priests were not only instilling the basics of Christianity in the pagans but also organizing primary education and vaccination of people against smallpox and other deadly diseases.

The most important merit of the church's activity was the dissemination of literacy, the development of writing among indigenous peoples, the translation of worship and books into the languages of local peoples. In addition to the educational function of the church, it performed an important informational role (here local residents learned about governmental decrees, declarations of war, peace, etc.) and performed the functions of the registry office: records about born, married and deceased people were written in metric books.

Historically, the territory of the modern Magadan region was part of the Irkutsk diocese until the year 1840. Subsequently, most of it was related to the Kamchatka diocese. Since 1869, its land was divided between the Yakut and Kamchatka dioceses, and in 1898 the territory of the latter was transferred to the Vladivostok diocese.

In 1840, St. Innocenty (Veniaminov) (1797-1879) became the first bishop of the newly established Kamchatka, Kuril and Aleutian diocese, later he became Metropolitan of Moscow (in 1868).

In 1823, a young family priest boldly responded to the appeal of the Holy Synod and decided to go as a missionary to the Aleutian Islands (Unalashka Island).

On May 7, 1823, Father Joahn (in monasticism, Innocenty) left Irkutsk with his aged mother, wife, one-year-old son, and brother. And from that moment on, he will spend his whole life in unceasing missionary work. Even then, his path ran through the city of Okhotsk, located on the shore of the Sea of Okhotsk.

The Saint made four trips across the territory of the present Magadan region (in 1842-1843, 18461847, 1850-1851 and 1861-1862). In ancient Kolyma villages, such as Gizhiga, Tauisk, Yamsk, Ola, Arman, Takhtoyamsk, he improved dilapidated churches, built new ones, opened schools; he baptized, married, taught people; he preached, did scientific research, and taught the local indigenous people various crafts.

The missionary's travel diaries, containing the appearance and life of the Okhotsk settlements, have been preserved. These observations subsequently formed the basis of his scientific works on geography, ethnography and linguistics, which made him a world-famous scientist.

One of his best works, "The Indication of the Way to the Kingdom of Heaven" (1833), was translated into different languages of the small peoples of Siberia and was published over 40 times. 
Thanks to the work of St. Innocenty the Yakuts heard the Word of God and worship in their native language for the first time in 1859.

The Kolyma residents still remember the educational activities of St. Innocenty:

- In 2015 on the Magadan Cathedral Square there was the grand opening and then the consecration of the monument to St. Innocenty Metropolitan of Moscow - the Apostle of Siberia and the Far East, the enlightener of the Kolyma land. In the same year, the ark with his relics was brought to the Holy Trinity Cathedral of Magadan;

- In 2016, the church was consecrated in honor of St. Innocenty of Moscow (the baptismal church of the Holy Trinity Cathedral in Magadan). The Sacrament of Holy Baptism is constantly being performed in this church today;

- In 2017, a chapel in honor of St. Innocenty of Moscow was consecrated in the airport terminal of Magadan;

- In 2017, the chapel of St. Innocenty of Moscow at the Holy Trinity Cathedral of Magadan was consecrated;

- In 2018, the church in the village of Debin was consecrated in honor of St. Innocenty of Moscow.

History has preserved the names of those clergy who worked on the territory of the Magadan region:

- Priest Stefan Popov (from 1839 to 1846 he served in the Tauisk Church of the Intercession);

- Priest Hilarion Chernykh (from 1846 to 1875 he served in the Tauisk Church of the Intercession);

- Priest Innocenty Chernykh (from 1875 to 1878 he served in the Tauisk Church);

- Priest Nikolay Chernykh (from 1878 to 1895 he served in the Tauisk Church; from 1883 appears in the metric books of the Epiphany Church of Ola; from 1889 to 1893 archpriest of the Yamsk Annunciation Church);

- Priest Vladimir Mikhalchuk (from 1895 to 1898 first archpriest of the Church of Ola, from 1896 priest in the Tauisk Church);

- Priest Alexey Apellesov (from 1898 he served in the Tauisk Church);

- Priest Innocenty Mamin (from 1899 to 1900 he served in the Church of Ola);

- Priest Mikhail Masyukov (in 1840-1850s he served in Yamsk Church);

- Priest Peter Mikhailov (from 1893 to 1911 he served in Yamsk Church);

- Priest Serapion Mamin (from 1911 to the end of the 1920s (1927?) he served in Yamsk Church);

- Priest Serafim Chernykh (from June 1900 to 1911 and in 1917-1918 he served in the Tauisk Church, from June 1918 to 1921 he served in village Ola, according to Khakhovskaya L.N. in 1920 s he was a priest in the united Ola-Tauisk Church);

- Priest Clement Popov (from 1902 to 1907 he served in the Church of Ola);

- Priest John Povyrenov (born in 1882) (from January 1908 to 1913? he served in the Church of Ola, from 1912 - archpriest in the Church of Ola);

- Priest Alexander Nikonov (from 1911? to 1917? he served in the Tauisk Church);

- Priest Innocent Popov (from 1913 to 1918 he served in the Church of Ola).

At the beginning of the 20th century at the Seymchan Chapel, a new parish was formed from the inhabitants of Seymchan, Orotuk, parishioners of the Oymyakon, Yamsk, Tauisk and Ola churches. Shortly before the October Revolution, they built the Seymchan Church. However, data on the clergy who nurtured the community spiritually were not preserved. 
2. Kolyma during the period of persecution of Christianity: new martyrs, confessors, pious devotees. By the end of the 1930s, all the temples and chapels in the Kolyma (there were about 10 of them) were destroyed. For many years, the development of spiritual life in the Far Northeast has stopped. Only in 1945, the Khabarovsk diocese was re-established, which included the entire Far East.

The February Revolution of 1917 was perceived differently and ambiguously by the population. And even the Synod's appeal in March reported: "God's will has been accomplished. Russia has embarked on a new path of state life. God bless our great Motherland with happiness and glory on its new path".

The change in the political system may have seemed like a breath of freedom and the beginning of building a new, right path. Already in May 1917, the election of the diocesan clergy was introduced in the Russian Church, and elections of the ruling bishops were held in places. On February 15 of the same year, the village of Inya hosted a congress of the Okhotsk district clergy with the participation of the laity.

Literally a year later, it became clear that there is nothing to rejoice about, there is no confidence in the future: at the end of January 1918 a decree of the Council of People's Commissars "On the Separation of the Church from the State and the School from the Church" and the order of the People's Commissariat of State Charity "On the cessation of the issuance of funds for the maintenance of churches, chapels, clergy, teachers of religion and for the performance of church rituals".

Incomprehensible changes are taking place in the state system. An independent state Far Eastern Republic, including the Kamchatka region, was formed in April 1920 and existed until November 1922.

After the revolution, at the end of the civil war, at the Far Eastern Episcopal Conference of the Higher Church Administration Abroad, held in August 1922 in Nikolsk-Ussuriysk, it was decided to separate the Kamchatka see into an independent diocese (September 13, 1922), that included territory of the modern Magadan region. Bishop Daniil (Sherstennikov) was assigned to the see established in Okhotsk, but was arrested later that year.

The parishes are rapidly getting poorer, and even the unification of the Tauisk and Ola parishes does not help to solve material problems: in December 1920, even on Christmas Eve, it was not possible to hold a service in the Ola Church.

All metric books began to be withdrawn from churches in 1922-1923, according to the decree of Far Eastern Revolutionary Committee.

A new round of anti-religious propaganda was an attempt to introduce a calendar on October 1, 1929, abolishing the traditional seven-day week and Sunday.

According to the documents of the State Archives of the Magadan Region, from 1929 to 1931 there are no priests left in Kolyma, clergymen coming from Okhotsk hold services.

Unable to maintain and restore church buildings, communities give them to the state, subsequently clubs (Ola, Tauisk, Seymchan), village libraries (Yamsk), storages, public nursery (Arman) are organized in them.

Groups of militant atheists were organized (such a club was known in the village of Tauisk, gathering up to 30-40 people for anti-religious meetings).

Repressions are ramped up: clergymen and members of their families are deprived of suffrage (this information is preserved regarding the deprivation of the rights of the following persons, members 
of the known in the Far East priestly family: Chernykh Aleksandr Leontievich, Chernykh Varvara Leontyevna, Chernykh Ivan Petrovich, Chernykh Illarion Leontievich).

In the fight against the "prejudices" of the past, large values were needed. However, the results of the population census of January 1937 were declared defective and remained classified, and many of its participants were arrested and executed.

In 1937, the orders of the People's Commissar of Internal Affairs of the USSR on the return to the places of imprisonment of persons who had served their sentences and on the execution of those who were in custody were issued.

Harsh measures were implemented. Malakhov Afinogen Sergeyevich, Kamchadal, a native of Nayahan village of the Severo-Evensk Region, who was deprived of suffrage in 1924 and reinstated in 1936, was shot as minister of religion.

The same fate awaited in 1938 for Shakhurdin Artyom Georgievich, the church and village headman of the Arman church (according to the documents, it was the chapel assigned to the Tauisk Intercession Church, which was nurtured by the Tauisk and Ola priests).

In 1938, the sons of the Okhotsk clergy were convicted and shot: Kanaev Serafim Aleksandrovich, Mamin Petr Serapionovich, Chernykh Alexander Leontyevich, Chernykh Ivan Petrovich.

The names of some clergymen and laity who served their sentences and were shot in Kolyma are known: priest Sergiy Ananyev (served his sentence in village Atka), hieromonach Mikhail (Akhlestin), priest Nikolay Bakursky (died in Kolyma camps), priest Vasiliy Ruban, priest Arkadiy Chermenskiy (shot in Magadan), archpriest Grigory Ponomarev, hieromonach Gerasim (Egorov), archpriest Ivan Vereshchagin (shot in Yagodnoe district, camp "Partisan"), hieromonach Feodor (Dubot), archpriest Dimitri Krylov, priest Grigory Nikulin (died in prison in Kolyma), priest Mikhail Kozin, priest Vitaly (Bimbirekov), archpriest Sergiy Nogachevsky, priest Nikifor Kulik (died in Yagodnoe district), priest Vasily Bogomolov, priest Mikhail Klimentyev (died in the camp), priest Ivan Stefanovich, priest Dimitri Volokitin, priest Sergiy Gusev (died in custody), archpriest Pavel Burdukov, hieromonach Rafail (Melnichuk) (Atka), priest Joseph Telitsa (village Atka, shot for religious propaganda among prisoners), priest Nikolay Dymov (died in custody in Magadan camps), archpriest Trifon Stefanov, archdeacon Vasily Ryabenky, priest Vsevolod Popov, priest Joahn Shnyrev, priest Gavriil Gorshkov, priest Timofei Pochtarev, poet Alexander Solodovnikov (served his sentence in Seymchan), poetess Natalya Anufrieva, Varvara Sokolova, Alexandra Speranskaya, Mikhail Bakhilov, Feodosiy Gritsenko (he died in the Chai-Urya camp of the Susuman district) (Moscow Orthodox St. Tikhon Humanitarian University).

About a hundred parishioners of Kolyma churches were also in the execution lists.

The saints: monk-confessor of the Faith Barsanuphius of Kherson (canonized by the Ukrainian Orthodox Church) and martyr Joahn Kolesnikov also were in the Kolyma camps.

In the annals of the Magadan diocese, the names of saints are especially noted: the monk-confessor of the Faith Andronik (Lukash), the martyr Anna Shashkina, the holy martyrs Joahn and Vasily Kozyrev, the holy martyr Dimitry of Kazan, the holy martyr Grigory Serbarinov, reverend Iov of Ugla, the monk-confessor of the Faith Maria (Korepova), the holy martyr Eleazar Spiridonov, the holy martyr Peter Bogorodsky, the holy martyr Mikhail Okolovich, the holy martyr Vasily Bessonov (Diocese of Magadan and Sinegorye).

Among the prisoners of Kolyma known to us there are ascetics of piety (clergymen and laity distinguished by their Christian lives, who have passed the test of faith, but who are for one reason or another not saints) - Archbishop Benjamin (Novitsky) and hieroschemamonk Pavel (Gulinin). 
At present, there is an urgent problem of naming almost hundreds of our compatriots as holy new martyrs, but at the moment it cannot be solved due to the lack of access to the archives of law enforcement agencies and the law on the protection of personal data.

The memory of the victims of the great tragedy of the 20th century is sacredly honored by the inhabitants of Kolyma. The main symbol of Magadan - Cathedral of the Holy Trinity - is a unique church-monument to the victims of political repressions. In 2016, the lower church of the cathedral was consecrated in honor of the New Martyrs and confessors of the Russian Church.

3. Modern development: ruling bishops and major events. In recent history, the Magadan diocese, which included the Magadan region, the Chukotka autonomous region and the Kamchatka region, was formed by the decision of the Holy Synod of the Russian Orthodox Church of January 31, 1991. On February 23, 1993, the Petropavlovsk diocese in the territory of the Kamchatka region and on July 19, 2000, the Anadyr diocese in the territory of the Chukotka autonomous region were separated from its structure.

The revival of church life in Kolyma began in 1989, when the first Orthodox community was registered in Magadan by the efforts of the bishop of Khabarovsk and Vladivostok Gavriil (Steblyuchenko). The first Magadan church - of the Intercession of the Holy Mother of God - was arranged and consecrated in a small private house in the village of Solnechny (on the territory of the Intercession Convent).

The first Divine Liturgy in Magadan was celebrated on the feast of the Nativity of the Holy Mother of God on September 21, 1989. The Magadans came to the church, were baptized and took their first steps in church life. The walls of a small house could hardly accommodate believers. Then, in 1989 , the state authorities were petitioned for the construction of a new church.

In April 1990, Bishop Gavriil consecrated the site for the construction of the Descent of the Holy Spirit on the Apostles - the first church in the history of the city. A particle of the relics of St. George the Victorious was laid at its foundation.

On January 31, 1991, by the decision of the Holy Synod of the Russian Orthodox Church, the Magadan and Kamchatka Diocese was formed. It included the Magadan region, the Chukotka autonomous region and Kamchatka. For a short period (January 31 - April 21, 1991), Bishop of Irkutsk Vadim (Lazebny) was appointed her temporary manager.

The first Magadan archiereus was Bishop Arkady (Afonin), who was in the see from April 21, 1991 to November 1, 1993. At the beginning of the ministry, he bore the title of Magadan, Kamchatka and temporarily Sakhalin, nourishing a vast territory, which was subsequently divided into four separate dioceses. After the separation of the Petropavlovsk and Kamchatka dioceses from its structure in 1993, the diocese was called Magadan and Chukotka. On July 19, 2000, due to the formation of the Anadyr diocese in the territory of the Chukotka autonomous region, the diocese became known as the Magadan and Sinegorye diocese.

Under the rule of bishop Arkadiy, the construction of the Cathedral of the Descent of the Holy Spirit on the Apostles was completed. A huge contribution to the construction of the first cathedral church was made by the mayor of Magadan, G. E. Dorofeev. The cathedral was consecrated on February 2, 1992. Soon, it was decorated with icons donated by His Holiness Patriarch Alexy II. Among the shrines given by the High Priest is a copy of the Iveron Icon of the Mother of God, written on Athos in the 19th century.

During the two years of bishop Arkady's stay in the Magadan diocese, the construction of the Church of the Intercession of the Holy Mother of God, which later became the Holy Intercession Monastery, was completed. His Grace Arkady ordained the first priests who were to bring the light of Christ's truth to the inhabitants of the vast territories of the newly formed diocese. 
One of the most important events in spiritual life in the early years of the Magadan diocese was the visit to the Kolyma land of His Holiness Patriarch Alexy II of Moscow and All Russia in 1993. The delegation accompanying the Patriarch included the current Primate of the Russian Church - His Holiness Patriarch Kirill, Metropolitan of Smolensk and Kaliningrad back then. During the years of persecution, his father had carried the feat of profession of faith in the Kolyma camps for five years.

At the airport, His Holiness the Patriarch was met by Bishop Arkady, the regional governors and residents of the Kolyma capital. Addressing the Magadans, His Holiness Patriarch of Moscow and All Russia Alexy II said: "In the Far East and Siberia, the tornado of atheism swept the whole church life. There are no churches left; there are no shrines that were built. Everything has to be recreated. This land is really long-suffering. It was shed a lot of blood here; a lot of tears were shed by those who were convicted, exiled to Kolyma, innocently suffered during the years of repression".

At the Cathedral of the Descent of the Holy Spirit on the Apostles, His Holiness the Patriarch performed a prayer and a memorial service for all innocent victims in the Kolyma camps. After a joint prayer, the Primate of the Russian Church addressed the faithful with a sermon:

"Now, in front of this newly created Orthodox church in Magadan, we have made a prayer, prayer service to the Savior God, the Most Holy Mother of God and the New Martyrs of Russia, who died on many Russian calvary, were shot, died of hunger and cold in the difficult times that our longsuffering people had to endure", - said His Holiness.

After the service in the Magadan cultural center, His Holiness Patriarch Alexy II and Metropolitan Kirill of Smolensk and Kaliningrad met with the public of the Kolyma capital.

A significant contribution to the development of church life in the Northeast was made by Bishop Rostislav (Devyatov), who headed the diocese of Magadan and Chukotka for five years (November 28, 1993 - December 28, 1998). Under him, the diocesan administration found its premises, the diocesan library was organized, and the public organization Father's House appeared, which helps people suffering from alcoholism and drug addiction. The Union of Orthodox Youth and the city committee "For the moral revival of the Fatherland" were formed.

In 1993, the Okhotsky Ryad Orthodox TV Company was formed in Magadan. The TV channel had a big goal - to bring the light of the faith in Christ to the Kolyma people by broadcasting television programs dedicated to the history of the Church, the lives of saints, and the speeches of famous missionaries and theologians. The Okhotsky Ryad TV company still operates today.

The Cathedral of the Descent of the Holy Spirit on the Apostles was decorated with a new iconostasis, and also found new shrines - the ark with the relics of the holy saints of God, icons with particles of the relics of St. Seraphim of Sarov, Holy Martyr Charalampy, Saint Innocenty, Metropolitan of Moscow, Blessed Matronon of Moscow, Saint Tikhon, Patriarch of Moscow, Supreme Apostles Peter and Paul.

In July 1996, Bishop Rostislav and clergy of the diocese traveled to places of mass repression of Kolyma. One of these tragic places in the 1930s was the Serpantinka prison. Now at the place where machine-gun towers once stood, from which the entrance to the gates of this notorious prison was guarded, on the descent from the Khatynnah Pass in the Yagodninsky District of the Magadan region there is a monument erected on the initiative of the society "Search for Illegally Repressed" on May 12, 1991. It is a two-meter block of gray granite with a sharp break in the shape in the form of verkhonka (working gauntlet), as if emerging from under the ground. The detail of the memorial - round-shaped granite of much smaller size - is pierced through by a geological drill like a bullet. At the foot of the monument there is an inscription on an ash-black plate: "On this place in the 
1930s there was a Serpantinka prison. Tens of thousands of repressed citizens were executed here, the ashes of which rest in this valley".

In October 1996, in the center of Magadan, on the Alley of Remembrance, a chapel was erected in the name of St. Great Martyr George the Victorious (the construction was timed to the 51st anniversary of the Victory in the Great Patriotic War). By the end of 1996, a baptismal church was erected and consecrated in the name of St. John the Forerunner, the Baptist, located on the territory of the Cathedral of the Descent of the Holy Spirit on the Apostles. Three more churches were laid by the efforts of Bishop Rostislav: in honor of the Assumption of the Holy Mother of God in Pevek (Chukotka), the Annunciation of the Holy Mother of God in the village of Sinegorye, the temple of the Kazan Icon of the Mother of God in the suburb of Magadan was built and consecrated.

The most important event for the Magadan diocese was the solemn bringing in November 1997 of an honored copy of the miraculous Pochaev Icon of the Mother of God to Magadan. The icon was accompanied by Bishop (now Metropolitan) of Ternopil and Kremenets Sergiy. The Pochaev icon was met by many Magadans, the authorities of the region and the city. Subsequently, the shrine was taken to almost all parishes of Magadan and Chukotka diocese undivided back then, consecrating the entire vast territory of Kolyma and Chukotka.

In January 1999, the Magadan see was headed by Bishop Anatoly (Aksenov), who managed the diocese from December 28, 1998 to October 8, 2000. Under him the first female Intercession monastery began to operate in Magadan. In the spring of 2000, Bishop Anatoly consecrated the Church of the Annunciation of the Holy Mother of God in the village of Sinegorye. In the same year, in the village of Snezhniy in the Magadan region, the first children's Orthodox camp in the region, Rodnik, was opened.

In the fall of 2000, by the definition of the Holy Synod, the diocese was called Magadan and Sinegorye. Anadyr and Chukotka diocese were allocated from its composition.

In 2000 His Grace Feofan (Ashurkov), now the Metropolitan of Kazan and Tatarstan, became the first bishop, who bore the title of Magadan and Sinegorye. From the very first year of his ministry in Kolyma, His Grace Feofan laid the foundation for the region's most important church and public event - the Regional Christmas Educational Readings (2001). Since that time, Christmas readings in the Kolyma capital are held annually.

In 2001, His Grace Feofan laid the foundation for yet another Magadan tradition - on the feast of the Epiphany, the Great Consecration of the waters of the Sea of Okhotsk was first performed. Since that time, Cross Procession to the Gertner Harbor on the Feast of the Epiphany takes place annually.

At the initiative of Bishop Feofan, in the same year, a city medical conference and a seminar on the problems of rehabilitation of drug addicts took place; the first issue of the diocesan newspaper Kolyma Lampada was published. Another important event of 2001 was the opening of prayer rooms in the Internal Affairs Directorate of Magadan region and in the high-security prison in the village of Uptar.

The main merit of His Grace Feofan is the construction of the Trinity Cathedral, the spiritual heart of Kolyma. In January 2001, the Council of Territories under the leadership of the governor Tsvetkov V.I. unanimously decided to build the long-awaited cathedral in Magadan in honor of the Holy Life-giving Trinity.

With the appointment of the new governor of the Magadan region N.N. Dudov Cathedral construction continued at the expense of donations and extrabudgetary funds of the Special Economic Zone. 
In May 2003, by decision of the Holy Synod, Bishop Feofan was transferred to the Stavropol and Vladikavkaz diocese.

On May 7, 2003, the diocese was headed by Bishop Guriy (Shalimov). His Grace Guriy consecrated the St. Nicholas Church in Magadan (in 2004), the grotto chapel in honor of the Apostle Andrey the First-Called on the Ola Coast (at the site of the landing of the expedition of Yu.A. Bilibin in 1928), chapel in the name of Reverend Ilya Muromets on the board territory, the Church of the Vladimir Icon of the Mother of God in the village of Seymchan, the chapel of St. Alexy, Metropolitan of Moscow at the Juliet gold deposit in the Omsukchan district of the Magadan Region (in 2010). Awareness-building in the educational sphere was continued.

In July 2004, the first Divine Liturgy and the consecration of the Church of St. Nicholas the Wonderworker in Magadan were performed.

In 2003, the miraculous Albazin icon of the Mother of God "The Word of the Flesh" was brought to Magadan for worship. The icon was brought by the Archbishop of Blagoveshchensk and Tynda Gavriil (Steblyuchenko). He donated an accurate copy of this miraculous icon, which is now in the Cathedral of the Descent of the Holy Spirit on the Apostles.

On March 17, 2011, in the working Patriarchal residence in Chisty Lane, His Holiness Patriarch of Moscow and All Russia Kirill met with the governor of the Magadan region N.N. Dudov and Bishop of Magadan and Sinegorye Guriy.

His Holiness the Patriarch shared his memories of his visit to the Kolyma land, where his father, future archpriest Mikhail Gundyaev, was serving a sentence during the years of persecution. "Since childhood I had known a lot about the Kolyma land and the circumstances in which people were there in the 1930s, - told the Primate. - Therefore, having arrived for the first time in Magadan, I very deeply survived a meeting with this land".

N.N. Dudov informed the Holy Patriarch about the completion of the construction of the Holy Trinity Cathedral in Magadan and invited His Holiness to visit the Kolyma Region again and to consecrate the church. His Holiness Patriarch Kirill gratefully accepted the invitation.

On August 31, 2011 His Holiness Patriarch of Moscow and All Russia Kirill arrived in Magadan.

On September 1, 2011, the most important historical event in the life of Kolyma took place - His Holiness Patriarch of Moscow and All Russia Kirill performed the great consecration of the Holy Trinity Cathedral of Magadan and the Divine Liturgy in the newly consecrated church.

A few years later, the Holy Trinity Cathedral of Magadan became the main center of spiritual life in the Kolyma land. A Sunday school for children and adults was organized here, a conference room, a refectory, prothesis, office premises were equipped. On December 14, 2016 the baptismal church in honor of St. Innocent of Moscow was consecrated. On December 16, 2016 the Church and History Museum was opened. Festive concerts dedicated to church holidays and events of diocesan life, educational and church-social events, catechetical conversations before baptism, meetings of parishioners with the clergy and invited guests take place in the conference hall of the cathedral. The heyday of spiritual life in the Magadan diocese falls on a new period in its history.

By the decision of the Holy Synod of October 5-6, 2011 (Journal No. 110), archimandrite Joahn (Pavlikhin) was elected bishop of Magadan and Sinegorye.

On October 12, 2011, during the Liturgy in the Church of the Holy Right Prince Alexander Nevsky in Baltiysk, His Holiness Patriarch Kirill led the chirotony of archimandrite Joahn (Pavlikhin) to the Bishop of Magadan and Sinegorye. 
In December 2011, there was the first archpastoral visit of the bishop of Magadan and Sinegorye Joahn to the churches of the diocese, which included remote settlements of the region. From the first days of service in the Kolyma land His Grace set a goal - the construction of new churches in all settlements of the Magadan region, the provision of all churches of the diocese with full-time priests, the organization of educational and missionary activities. The construction of churches was started at the same time in 2011 (from 2012 to 2018, 31 churches were being built by philanthropists in almost all settlements of the Magadan Region; 15 of them were built, in total 54 churches were listed in Kolyma in 2018). The first clergymen from among the residents of Kolyma were ordained, for the first time in many years monastic tonsures were performed in Magadan. Already in 2012, seven priestly and eight deacon ordinations were performed. In 2014, the number of full-time clergy reached 30 people. Currently, almost all parishes of the diocese are provided with full-time clergy.

In 2011, the official website of the Magadan diocese was created and the newspaper Kolyma Evangelist was established. In 2013, a public Information and Publishing Council was established at the diocese.

Since 2012, close cooperation has been established with regional ministries and law enforcement agencies. The work of the relevant diocesan departments is organized and is gaining strength (the department for church charity and social ministry, the information and publishing department, the department for interaction with the Cossacks, the department for cooperation with the armed forces and law enforcement agencies, the department of prison service, the missionary department, the department for youth affairs, the department for religious education and catechesis).

On February 4, 2014 the Bishop of Magadan and Sinegorye Joahn and the governor of the Magadan region V.P. Pecheny signed a cooperation agreement between the Magadan diocese and the administration of the Magadan region. The agreement provides for interaction to preserve and strengthen the spiritual and moral potential of Russian society, national spiritual traditions, moral and patriotic education of youth. Such an agreement was concluded for the first time in the history of the diocese.

This period is also marked by the acquisition of shrines and the consecration of new temples.

On April 13, 2013, accompanied by Archbishop Alexander Pereyaslav-Khmelnitsky and Vishnevsky (Drabinko), Secretary of His Beatitude Metropolitan Vladimir of Kiev and All Ukraine, the relics of the holy monk-confessor of the Faith Andronik (Lukash) were delivered to the Holy Trinity Cathedral of Magadan from the Glinsk monastery.

An important event of 2014 was the bringing of the copy of the miraculous icon of the Mother of God "The Tsaritsa" from the Athos Monastery Vatoped.

On August 22, 2015, bishop Joahn consecrated the Church of the Transfiguration of the Lord in the village of Palatka. Then, on the square near the newly consecrated church, the monument to the holy saints Prince Peter and Princess Fevronia of Murom was opened and consecrated.

On January 25, 2016, on the day of commemoration of the holy martyr Tatiana, Bishop Joahn of Magadan and Sinegorye performed the minor consecration of the Tatiana Church at Northeastern State University. On March 26 of the same year, the relics of the saint patron of students were brought to the church from Rome.

The main event of church and public life in Kolyma in 2015 was the celebration of the installation and unveiling of the monument to St. Innocent of Moscow, Apostle of Siberia and America, enlightener of the Kolyma land on Cathedral Square of Magadan. On September 19, 2015, the ark with some part of the relics of St. Innocenty of Moscow was brought to Magadan from the TrinitySergius Lavra. 
On February 1, 2016 His Holiness Patriarch of Moscow and All Russia Kirill elevated Bishop Joahn of Magadan and Sinegorye to the rank of Archbishop. The exaltation was performed at the Divine Liturgy at the Cathedral of Christ the Savior in Moscow on the seventh anniversary of the intronization of the Primate of the Russian Church.

On September 5, 2018, the archpriest of the Holy Great Monastery Vatoped of Mount Athos, Archimandrite Ephraim (Kutsu) arrived in Magadan. Father Ephraim brought the ark with part of the relics of the reverend Maxim the Greek, as well as copies of the icons of the Mother of God "The Tsaritsa" and "Joy and Consolation". A copy of the miraculous icon of the Mother of God "Joy and Consolation" was brought as a gift to the Holy Trinity Cathedral for believers to worship.

Churches that were destroyed during the years of persecution are being recreated. Thus, on August 5, 2017, the Church of the Epiphany of the Lord was consecrated in the village of Ola. The new church is an enlarged copy of the pre-revolutionary church building.

Moral ideals in society are also being recreated. The education of the younger generation in the spirit of traditional religious and cultural values is a necessary condition for the spiritual revival of the Fatherland. The Magadan diocese together with the Ministry of Education and Youth Policy of the Magadan region and the Department of Education of the City Hall of Magadan implements Orthodox-oriented projects in the regional education system - in kindergartens, schools and higher educational institutions. All of them are aimed at forming the foundations of a Christian outlook and moral principles in children, adolescents and youth.

Active cooperation in the field of education is carried out with the largest university in the region Northeastern State University.

Since 2012, the subject "Fundamentals of Orthodox Culture" has been taught in schools in Magadan and the Magadan region. It acquaints schoolchildren with the cultural heritage of Orthodoxy, icon painting and architecture, religious customs and traditions, which had a significant impact on the formation of the mentality and character of Russian people. Studying the foundations of Orthodox culture contributes to the formation of the moral sphere of students, revealing the foundations of Christian morality. The state standard currently involves the study of Orthodox culture in schools during the 4th grade, but an educational institution may go beyond this. Thus, in Magadan English Gymnasium students get acquainted with the Orthodox culture throughout most of the learning process as part of the program "Return to the roots: the spiritual and moral development of students in the context of the integration of Orthodox culture in the educational process of educational institutions".

One of the important achievements of the gymnasium is Easter student readings. This city conference has been held annually since 2013. The experience of holding the forum is unique - this is the first Easter student readings in Russia.

In 2015, the Parliamentary Christmas Meetings were held for the first time in Magadan. The event was held in the large hall of the Government of the Magadan region in the framework of the XVI regional Christmas educational readings "Tradition and Innovation: Culture, Society, Personality".

Every year since 2012, the Magadan Regional Universal Scientific Library named after A.S. Pushkin has been holding an educational public forum "Day of the Orthodox Book", the participants of which are representatives of the clergy, regional authorities, public figures, teachers and scientists.

Traditionally, the forum opens an exhibition of novelties of church book publishing, which is organized as part of the annual All-Russian celebration dedicated to the memorable historical date of the publication of "The Apostle" - the first printed book in Russia by Ivan Fedorov. 
It has become a good tradition to hold Regional Cyril and Methodius readings, which have been held annually since 1998 on May 24 - the Day of Slavic Writing and Culture.

Every year in Magadan, a regional stage of the All-Russian competition in the field of pedagogy and work with preschool children and youth under 20 years old is held for the award "For the moral deed of a teacher", as well as the international competition of children's creativity "The Beauty of God's World" and the All-Russian contest for schoolchildren on the basics of Orthodox culture.

In 2015, on the initiative of the Magadan diocese, the activities of the Magadan social movement "Kolyma is for life!" were organized and an agreement on cooperation between the diocese and the Ministry of Health and Population Policy of the Magadan region was signed. The agreement provides for interaction on issues of protecting the health of mothers and children and the revival of traditional family values. The most important issue of our time is to convey to people the inadmissibility of killing a child in the womb of the mother.

On June 17, 2017, the grand opening of the Magadan Diocesan Center for Humanitarian Aid "Kolyma is for life" took place. The purpose of the center is to provide clothing, food and psychological assistance to pregnant women in difficult situations, single mothers, large and lowincome families.

\section{Discussion}

The modern history of spiritual life in the Kolyma land is the history of the revival of shrines and the restoration of traditions that unite our multinational state. Spiritual traditions are an important element of the cultural development of society, transmitting life values from generation to generation. For over a thousand years, Orthodox spiritual traditions have been the core for Russian culture; they serve as the key to understanding Russian identity and cultural code.

Human values determine the path for the further development of society. In the Far East, in our small homeland - Kolyma, a special relationship has developed over the years to the main value of our region - not the gold reserve, but to living people.

The inhabitants of the North are more open, welcoming, friendly, always come to the rescue in difficult times. The harsh climate fosters a strong character and fortitude. Volitional qualities determine the life of a person, contributing to survival, not only physical but also spiritual. Therefore, spiritual support is no less important for a person than his state of health. Understanding the basics of spiritual life helped our compatriots, who settled in the Far Eastern territories in difficult conditions.

The results obtained help to formulate the answer to the question: what helps a person to survive under extreme conditions, to overcome countless trials of the North. Our article supplements and expands information from the works of Magadan researchers, clarifies the definition of periods and presents previously unpublished rich factual data that provides the basis for further research.

Due to the privacy of departmental archives, many data on the history of Orthodoxy in Kolyma are still closed. Meanwhile, a large number of studies can and should be devoted to the personalities of Kolyma new martyrs and confessors.

\section{Conclusion}

Summarizing our research, we note the enormous potential of further work and the need to continue research on the history of Orthodoxy in the Magadan region. The archives of GAMO (State Archive of Magadan Region) and the data of departments on the laity and clerics repressed in the territory of the Magadan region can serve as rich material for this. 
Having passed through the era of discoveries and the many difficulties of formation in the 17th-19th centuries, having survived the trials in the crucible of suffering in the 20th century, Kolyma is rightfully considered the "Russian Golgotha". In this light, the 1990s can be considered the beginning of the period of "resurrection" of spiritual life in our region.

The restoration of faith and religious self-awareness contributed to the development of traditions and culture, the maintenance of value orientations and moral ideals in society.

In addition to enlightenment, the Church's humanitarian mission in the modern period becomes the leading one: organizations are created to help people in difficult situations, food, clothing and advisory assistance is provided. The taken measures for support help solve the demographic and moral problems of modern society, because its human potential was and remains the main resource of our region and the entire Far East.

Thus, for the first time we give a holistic picture of the history of Orthodoxy in Kolyma and publish previously unpublished information: we introduce a periodization of the history of the Russian Orthodox Church in the Magadan region and sequentially, based on factual material, describe each period. The main attention in our article is concentrated on human personalities - those whose selfless work has created and is creating spiritual life in Kolyma.

\section{References}

John (Pavlikhin), archbishop of Magadan and Sinegorye. (2016). Orthodox Kolyma. Magadan; Vladimir: VIT-print.

Aruyeva, N.A. (2015). People and Fates: (pages of the history of the Chernykh clan). Magadan Local Historian, 1, 10-17.

Barenberg, A., Wilson, T., Kinnear S., Maddox, S., Viola, L. (2017). New directions in Gulag studies: a roundtable discussion. Canadian Slavonic Papers. 59(3-4) 376-395. Retrieved from: https://doi.org/10.1080/00085006.2017.1384665 (Accessed on April 16, 2020).

Diocese of Magadan and Sinegorye. New Martyrs and Confessors of Kolyma: Information Project of the Magadan Diocese. Diocese of Magadan and Sinegorye. Retrieved from: http://kolyma-martyrs.pravorg.ru (Accessed on February, 11, 2019).

Engel, B.A., Martin, J. (2015). Russia in World History. New York: Oxford University Press, 137139.

Hanson, F. (2001). The influence of the regional diversity factor on the economic transformation of Russia. Forecasting Problems, (3), 78-87.

Higgins, A. (2019). It's 50 Below. The Past Is a Horror Show. You'd Dream of Escaping Too. The New York Times, December, 2019. Retrieved from: https://www.nytimes.com/2019/12/31/world/europe/russia-magadan-siberia.html (Accessed on April 16, 2020).

Khakhovskaya, L.N. (2004). Okhotsk churches in the 19th - early 20th centuries (of Gizhiginsk, Tauisk, Yamsk and Ola). Materials on the history of the North of the Far East. Northeast Science Center Far Eastern Branch of the Russian Academy of Sciences, Northeast Complex Research Institute; Magadan: Northeast Complex Research Institute, 5-25.

Knox, Z. (2005). Russian society and the Orthodox Church: religion in Russia after communism. London; New York: RoutledgeCurzon, BASEES/RoutledgeCurzon series on Russian and East European studies, 13, 247-250. 
Matyushova, E.V. (2016). Echo of the events of 1917. 1917 - 2017: lessons of the century. XVII regional Christmas educational readings reports digest. Magadan: Northeast State University, 183-186.

Moscow Orthodox St. Tikhon Humanitarian University. New martyrs, confessors, who suffered for Christ during the years of persecution of the Russian Orthodox Church in the 20th century. Moscow Orthodox St. Tikhon Humanitarian University. Retrieved from: http://martyrs.pstbi.ru/bin/code.exe/frames/m/ind_oem.html/charset/ans (Accessed on February 11, 2019).

Onion, A., Sullivan, M., Mullen, M. (2018). Gulag. Retrieved from: https://www.history.com/topics/russia/gulag (Accessed on April, 16, 2020).

Steinberg, M.D., Coleman, H.J. (2007). Sacred stories: religion and spirituality in modern Russia. Bloomington; Indianapolis: Indiana university press, VIII, 397-401. 